\section{BIOCHEMICAL ASPECTS OF NEUROLOGICAL DISORDERS}

Edited by J. N. Cumings and M. KREMER. Pp. 230. Blackwell Scientific Publications, Oxford. 1960. 37s. $6 \mathrm{~d}$.

In this book an attempt has been made to cover all apsects of neurological disease known to be associated with biochemical dysfunction. The articles, which are written by experts in the field, are mostly paired, the first of the pair discussing biochemical and pathological aspects of the disease, and the second dealing with the same condition from a more clinical point of view. Sometimes the connection with biochemistry seems rather tenuous, and in the second chapter on B vitamins too much space seems to be given to pernicious anaemia in its non-neurological aspects, though the historical summary of this subject is most interesting. There are excellent chapters on porphyrins (it is a pity that no references are given to these), and on biochemical disorders of muscle.

Neurological biochemistry is a rapidly expanding subject, with great future possibilities. This book provides a useful and interesting review of the present state of knowledge in the field, and relates the biochemical findings to clinical syndromes.
TREATMENT OF CANCER AND ALLIED DISEASES

\section{Vol. III. Tumours of the Head and Neck}

Edited by George T. Pack, M.D., F.A.C.S., and Irving M. Ariel, M.D., F.A.C.S. Second edition. Pp. 781 + xviii, with 1,028 illustrations. London: Pitman Medical Publishing Co. Ltd. 1959. fiI I Is.

The third volume of this nine-volume work is devoted to the treatment of malignant tumours of the head and neck, but includes a wide survey of the relevant anatomy and pathology and for some regions gives an interesting historical account of the development of treatment. The general principles of treatment of anaesthesia and of pre- and postoperative care are fully discussed. Individual regions are dealt with in great detail by 70 different authors drawn from an international field, and a careful balance struck between surgery and radiotherapy and stress laid on combined methods of treatment.

The whole volume is beautifully produced, contains a wealth of excellent illustrations, photographs and diagrams and includes an extensive bibliography and a very adequate index.

References continued from Page 405. F. D. H. Slater, M.A., M.B., M.R.C.P.

14. JONES, K. M., LLOYD-JONES, R., RIONDEL, A., TAIT, J. F., TAIT, S. A. S., BULBROOK. R. D., and GREENWOÖD, F. C. (1959), Acta endocr. (Kbh.).

15. KAGAWA, C. M., CELLA, J. A., an I VAN ARMAN, G. C. (1957,) Science, 126, IOI 5 .

I6. KERR, D. N. S., READ, A. E., HASLAM, R. M., and SHERLOCK, S. (I958), Lancet, ii, ro84.

16a. KERR, D. N. S., READ, A. E., HASLAM, R. M., and SHERLOCK, S. (1960), Personal communication.

17. KISTLER, H., SHELLEY, T. F., and FRAWLEY, T. F. (1959), Clin. Res. Proc., 7, 254.

18. LANDAU, R. L., BERGENSTAL, D. M., LUGIBIHL, K., and KASCHT, M. E. (1955), Ұ. clin. Endocr., 15, I 194.

19. LARAGH, J. H. and STOERK, H. C. (1957), F. clin. Invest., 36, 383 .

20. LIDDLE, G. W. (1957), Science, 126, 1016.

21. LIDDLE, G. W. (1958), Archl intern. Med., 102, 998.

22. LUETSCHER, J. A., Jr. (1958), Arch. intern. Med., 102, 3 I4.

23. MCCRORY, W. W., and EBERLEIN, W. R. (1958), F. clin. Invest., 37, 917.

24. MORRISON, R. S., and CHALMERS, T. C. (1958), Clin. Res. Proc., 6, 300 .

25. RENOLD, A. E., CRABBE, J., HERNANDO-AVENDANO, L., NELSON, D. H., ROSS, E. J., EMERSON, K., JR., and THORN, G. W. (1957), New Engl. F. Med., 256, i6.

26. ROSS, E. J., and BETHUNE, J. E. (1959), Lancet, i, 127.

27. SALASSA, R. M., MATTOX, V. R., and POWER, M. H. (1958), भ̆. clin. Ëndocr., 18, 787.

28. SHALDON, S., MCLAREN, J. R., and SHERLOCK, S. (1960), Lancet, i, 609 .
29. SIMPSON, S. A., TAIT, J. F., and BUSH, I. E. (r952), Lancet, ii, 226.

3o. SKELTON, F. R. (1959), Physiol. Rev., 39, I62.

31. SLATER, J. D. H., MOXHAM, A., HUR'TER, R., and NABARRO, J. D. N. (1959), Lancet, ii, 93 I.

32. SLEISENGER, M. H., RICHARD, J. O., KOWLESSAR, D., CLARKSON, B., THOMPSON, D., and PETERSON, R. E. (1959), Clin. Res. Proc., 7, 37.

33. STURTEVANT, F. M. (I959), Endocrinology, 64, 299.

34. SUMMERSKILL, W. H. J., and CRABBE, J. (I957), Lancet, ii, 1091 .

35. TAI'T, J. F., SIMPSON, S. A., and GRUNDY, H. M. (I952), Ibid., $\mathbf{i}, \mathbf{1} 22$.

36. TAYLOR, F. F., and FALOON, II. W. (1 959), 7. clin. Endocr., 19, 1683 .

37. ULICK, S., LARAGH, J. H., and LIEBERMAN, S. (1958), Trans. Ass. Amer. Physns., 71, 225.

38. VENNING, G. R. (I960), personal communication.

39. WIGGINS, R. A., HUTCHIN, M. E., CARBONE, J. V., and DOOLAN, P. D. (1 959), Proc. Soc. Exper. Biol. \& Med., 100, 625 .

40. WOLFE, S. J., FAST, B., STORMONT, J. M., and DAVIDSON, C. S.'(1957), New Engl. F. Med., 257, 2 I 5.

4r. WOLFF, H. P., KOCZOREK, K. R., and BUCHBORN, E. (I957), Lancet, ii, 63 .

42. WOLFF, H. P., KOCZOREK, K. R., and BUCHBORN, E. (1958) 'International Symposium on Aldosterone,' p. I93. J. \& A. Churchill Ltd. 